\title{
Induction of bone marrow-derived cells myogenic identity by their interactions with the satellite cell niche
}

\author{
Kamil Kowalski ${ }^{1}$, Matthieu Dos Santos ${ }^{2,3}$, Pascal Maire $^{2,3}$, Maria A. Ciemerych $^{1}$ and Edyta Brzoska ${ }^{*}$
}

\begin{abstract}
Background: Skeletal muscle regeneration is possible thanks to unipotent stem cells, which are satellite cells connected to the myofibers. Populations of stem cells other than muscle-specific satellite cells are considered as sources of cells able to support skeletal muscle reconstruction. Among these are bone marrow-derived mesenchymal stem cells (BM-MSCs), which are multipotent, self-renewing stem cells present in the bone marrow stroma. Available data documenting the ability of BM-MSCs to undergo myogenic differentiation are not definitive. In the current work, we aimed to check if the satellite cell niche could impact the ability of bone marrow-derived cells to follow a myogenic program.

Methods: We established a new in-vitro method for the coculture of bone marrow-derived cells (BMCs) that express CXCR4 (CXCR4 ${ }^{+}$BMCs; the stromal-derived factor-1 (Sdf-1) receptor) with myofibers. Using various tests, we analyzed the myogenic identity of BMCs and their ability to fuse with myoblasts in vitro and in vivo.

Results: We showed that Sdf-1 treatment increased the number of CXCR4 ${ }^{+} B M C s$ able to bind the myofiber and occupy the satellite cell niche. Moreover, interaction with myofibers induced the expression of myogenic regulatory factors (MRFs) in CXCR4 ${ }^{+} B M C S$. CXCR4 ${ }^{+} B M C s$, pretreated by the coculture with myofibers and Sdf-1, participated in myotube formation in vitro and also myofiber reconstruction in vivo. We also showed that Sdf-1 overexpression in vivo (in injured and regenerating muscles) supported the participation of CXCR4 ${ }^{+} B M C s$ in new myofiber formation.

Conclusion: We showed that $C X C R 4^{+} B M C$ interaction with myofibers (that is, within the satellite cell niche) induced CXCR4 ${ }^{+} B M C$ myogenic commitment. CXCR4 ${ }^{+} B M C s$, pretreated using such a method of culture, were able to participate in skeletal muscle regeneration.
\end{abstract}

\section{Background}

The bone marrow is a source of numerous cell populations. Among them are hematopoietic stem cells (HSCs) and bone marrow-derived mesenchymal stem cells (BM-MSCs). BM-MSCs are multipotent, self-renewing stem cells that are present in the mammalian bone marrow stroma [1-3]. They play a role in the growth and turnover of the bone and formation of the hematopoietic microenvironment [1-3]. In the mouse, subcutaneously transplanted BM-MSCs form bone and bone marrow that can be colonized by host epithelium and hematopoietic cells [4-7]. Moreover, it was shown that a single BM-MSC

\footnotetext{
* Correspondence: edbrzoska@biol.uw.edu.pl

'Department of Cytology, Faculty of Biology, University of Warsaw,

Miecznikowa 1 St, 02-096 Warsaw, Poland

Full list of author information is available at the end of the article
}

can give rise to osteogenic-, chondrogenic-, and adipogenic-derived cells, demonstrating its multipotency $[4,8,9]$. The ability of BM-MSCs to self-renew their population in vivo after serial transplantation has also been documented [10]. Thus, BM-MSCs fulfill the strict criteria characterizing multipotent stem cells: the ability to self-renew and differentiate into several cell types both in vitro and in vivo.

The ability of BM-MSCs to manifest myogenic potential is still controversial [1]. Human CD146 ${ }^{+}$BM-MSCs were shown to be unable to undergo myogenic differentiation when transplanted into heterotopic sites or in vitro cultured in differentiating medium, i.e., in the presence of horse serum [11]. Thus, it was concluded that BM-MSCs do not present naive myogenic potential. However, the myogenic identity of BM-MSCs could be

(C) The Author(s). 2018 Open Access This article is distributed under the terms of the Creative Commons Attribution 4.0 International License (http://creativecommons.org/licenses/by/4.0/), which permits unrestricted use, distribution, and 
induced in vitro by overexpression of Notch intracellular domain (NICD) [12], $\beta$-catenin [13], Pax3 [14], or coculture with myoblasts, as well as in vivo by transplantation into regenerating skeletal muscle [15-23].

Under physiological conditions, skeletal muscle regeneration is possible thanks to satellite cells, which are muscle-specific unipotent stem cells occupying the myofiber niche localized between the basal lamina sheet of extracellular matrix (ECM) and the myofiber plasma membrane [24, 25]. The satellite cells express M-cadherin and CD34 which play important role in adhesion to the myofiber [26-28], as well as integrin $\alpha 7$ and $\beta 1$, dystroglycan that binds laminin present in the ECM $[29,30]$, and syndecan- 3 and syndecan- 4 that act as coreceptors for integrins [31]. One of the receptors that is critical for the maintenance of satellite cell quiescence is Notch [32, 33]. The lack of Notch signaling leads to spontaneous satellite cell differentiation [33]. Satellite cells, activated in the case of muscle damage, proliferate, migrate, and differentiate into myoblasts and then myocytes that fuse to form multinucleated myotubes and myofibers. As a result, damaged muscle becomes reconstructed [24, 25]. Importantly, some of the satellite cells do not form multinucleated myotubes but self-renew and return to quiescence, supplying a satellite cell pool [24]. Satellite cell activation and satellite cell-derived myoblast proliferation and differentiation depend on the precisely orchestrated expression of myogenic regulatory factors (MRFs) such as Myod1 and Myf5, and finally myogenin $[34,35]$. Importantly, the satellite cells fate is determined by extrinsic factors present within the local environment, in other words in the satellite cell niche, which includes growth factors, cytokines, adhesion molecules, and ECM that is composed of collagen IV, collagen VI, laminin-2, laminin-4, fibronectin, entactin, perlecan, decorin, and other proteoglycans [36-39]. Such an environment is formed by various cells present in intact or regenerating muscle, such as vessel-associated cells, immune cells, fibroadipogenic progenitors (FAPs), fibroblasts, and myofibers [36]. The satellite cell niche changes drastically in the case of muscle injury [36-39]. First, muscle injury generates an inflammatory process that affects the integrity of the niche, but which is required to remove the damaged myofibers, induce satellite cell proliferation and differentiation, and finally to restore the muscle homeostasis [36, 37]. Besides immune cells, damaged myofibers, fibroblasts, endothelial cells, and FAPs also appear as a source of growth factors, cytokines, and ECM required for efficient muscle regeneration [36, 38].

In the present work, we focused on the bone marrow-derived cells (BMCs), which is the cell population that is isolated from bone marrow and contains the fraction of BM-MSCs. In our previous studies we showed that in-vitro cultured mouse CXCR $4^{+} \mathrm{BMCs}$ are able, with low frequency, to fuse with $\mathrm{C} 2 \mathrm{C} 12$ myoblasts
[40]. We also proved that stromal-derived factor-1 (Sdf-1) treatment led to increased tetraspanin CD9 expression facilitating $\mathrm{CXCR} 4^{+} \mathrm{BMC}$ fusion with $\mathrm{C} 2 \mathrm{C} 12$ myoblasts [40]. Currently, we have tested the myogenic potential of a BMC subpopulation that expresses CXCR4, a receptor for Sdf- 1 which is the chemokine belonging to the cytokine family that plays an important role in stem cell mobilization [41]. We have established a new coculture system in which CXCR4 ${ }^{+}$BMCs are permitted to interact with myofibers that provide the niche for satellite cells. Using such a method we were able to analyze if the tested cells could colonize the satellite cell niche in vitro and if such interactions could induce their myogenic engagement.

\section{Methods}

The animal studies were approved by the Local Ethics Committee No. 1 in Warsaw, Poland (permit number 591/2014 and 046/2016) and Ethical Paris Descartes Cmmittee, France (CEEA34.PM.073.12) according to the European Union Directive on the approximation in laws, regulations, and administrative provisions of the Member States regarding protection of animals used for experimental and scientific purpose [42, 43].

\section{Isolation of CXCR4 ${ }^{+} \mathrm{BMCs}$}

A whole bone marrow cell population was obtained from the tibialis and femoris bone of 3-month-old male C57BI6N-lacZ mice expressing $\beta$-galactosidase $(\beta$-gal). Bone marrow cells were washed from bones using phosphate-buffered saline (PBS) and centrifuged in Histopaque 1077 gradient (Sigma-Aldrich) to remove erythrocytes. BMCs expressing CXCR4 $\left(\mathrm{CXCR}^{+} \mathrm{BMCs}\left(\beta-\mathrm{gal}^{+}\right)\right)$ were then selected using magnetic columns with antibody against CXCR4 and rabbit secondary antibody conjugated with paramagnetic particles accordingly to the manufacturer's instructions (Miltenyi Biotec).

\section{Single myofiber isolation}

Gastrocnemius muscles were isolated from 3-month-old male C57BI6N mice according to the method of Rosenblatt et al. [44]. Briefly, mice were killed by cervical dislocation and the muscles were carefully isolated from tendon to tendon, divided into smaller parts, and digested in $0.2 \%$ collagenase type I (Sigma-Aldrich) in Dulbecco's modified Eagle's medium (DMEM) at $37{ }^{\circ} \mathrm{C}$ for $2 \mathrm{~h}$. Single myofibers were separated using pipette tips with a capillary. Myofibers were washed in PBS and intact, long myofibers were selected. Each myofiber was carefully transferred into a single hanging drop of DMEM supplemented with $20 \%$ fetal bovine serum (FBS), 10\% horse serum (HS), 0.5\% chick embryo extract (CEE), and $1 \%$ penicillin/streptomycin localized on the cover of a Petri dish. The cover was turned upside down 
and placed on the base of the same Petri dish filled with PBS to prevent evaporation of the hanging drops, as previously described [45].

\section{Coculture of $\mathrm{CXCR4} 4^{+} \mathrm{BMCs}\left(\beta-\mathrm{gal}{ }^{+}\right)$and myofibers}

A single myofiber was selected and transferred together with approximately $100 \mathrm{CXCR}^{+}{ }^{+} \mathrm{BMCs}$ expressing $\beta$-gal $\left(\mathrm{CXCR} 4^{+} \mathrm{BMCs}\left(\beta-\mathrm{gal}^{+}\right)\right)$into a hanging drop of DMEM supplemented with $20 \%$ FBS, 10\% HS, 0.5\% CEE, and 1\% penicillin/streptomycin. CXCR4 ${ }^{+} \mathrm{BMCs}\left(\beta\right.$-gal $\left.{ }^{+}\right)$were cocultured with the myofiber for 5 days in control or Sdf- 1 (100 ng/ml)-supplemented medium.

\section{Coculture of fibroblasts and myofibers}

Fibroblasts were isolated from the ears of 3-month-old male C57BI6N-lacZ mice expressing $\beta$-gal according to a standard protocol [46] and cultured in DMEM supplemented with $20 \% \mathrm{FBS}, 10 \% \mathrm{HS}, 0.5 \% \mathrm{CEE}$, and $1 \%$ penicillin/streptomycin, and passaged three times. Next, 100 fibroblasts and a single myofiber were cocultured for 5 days in a hanging drop of DMEM supplemented with $20 \%$ FBS, 10\% HS, 0.5\% CEE, and 1\% penicillin/streptomycin. Fibroblasts were cultured in control or Sdf-1 $(100 \mathrm{ng} / \mathrm{ml})$-supplemented medium.

\section{Analysis of $\mathrm{CXCR4}{ }^{+} \mathrm{BMCs}\left(\beta-\mathrm{gal}^{+}\right)$cocultured with myofibers in monolayer culture}

After 5 days coculture of $\mathrm{CXCR} 4^{+} \mathrm{BMCs}\left(\beta-\mathrm{gal}^{+}\right)$with myofibers, they were transferred and washed three time in PBS to eliminate the cells that were not attached to the myofiber. Myofibers with attached CXCR4 ${ }^{+} \mathrm{BMCs}\left(\beta\right.$-gal $\left.{ }^{+}\right)$ were then transferred to six-well dishes covered with Matrigel (Becton Dickinson) and cultured for 14 days in DMEM supplemented with 20\% FBS, 10\% HS, 0.5\% CEE, and $1 \%$ penicillin/streptomycin. After 14 days, the cultures were analyzed using a Nikon Eclipse TE200 microscope equipped with Hoffman contrast.

\section{Detection of $\beta$-galactosidase activity}

After 14 days of monolayer culture, the cells which migrated from myofibers were fixed with $0.5 \%$ glutaraldehyde (Sigma) for $10 \mathrm{~min}$. Next, cells were washed in PBS, incubated in $1 \mathrm{mM} \mathrm{MgCl} 2$ for $5 \mathrm{~min}$, and exposed to X-gal working solution $(40 \mathrm{mg} / \mathrm{ml} \mathrm{X}$-gal, $5 \mathrm{mM}$ $\mathrm{K}_{3} \mathrm{Fe}(\mathrm{CN})_{6}, 5 \mathrm{mM} \mathrm{K} \mathrm{K}_{4} \mathrm{Fe}(\mathrm{CN})_{6} \cdot \mathrm{H}_{2} \mathrm{O}, 2 \mathrm{mM} \mathrm{MgCl}_{2}$ in PBS) until a blue color developed. Three independent experiments were performed.

\section{Transplantation of $\mathrm{CXCR4}{ }^{+} \mathrm{BMCs}\left(\beta-\mathrm{gal}^{+}\right)$into regenerating muscle}

The gastrocnemius muscles of 3-month-old male C57BI6N mice were injured by injection of $25 \mu \mathrm{l} 0.2 \mathrm{mM}$ cardiotoxin (ctx; Latoxan) into both muscles. After 3 days of regeneration, $\mathrm{CXCR} 4^{+} \mathrm{BMCs}\left(\beta-\mathrm{gal}^{+}\right)$were transplanted into the muscles. The pretreated CXCR4 ${ }^{+} \mathrm{BMCs}\left(\beta-\mathrm{gal}^{+}\right)$ cocultured with myofibers and Sdf-1 and control CXCR4 ${ }^{+} \mathrm{BMCs}\left(\beta-\mathrm{gal}^{+}\right)$, in other words freshly isolated from bone marrow, were injected into regenerating muscles. Each muscle received 100,000 cells.

\section{Transplantation of $\mathrm{CXCR4}{ }^{+} \mathrm{BMCs}\left(\beta\right.$-gal $\left.{ }^{+}\right)$into regenerating muscles electroporated with Sdf-1}

The tibialis anterior of 3-month-old male C57BI6N mice were injured by injection of $35 \mu \mathrm{l} 12 \mu \mathrm{M}$ ctx (Latoxan) into the muscles of both legs. After 4 days of ctx-induced regeneration, muscles were electroporated with a NEPA21 electroporator (Nepagene). The plasmids used were pUNO1 encoding mouse CXCL12 (SDF1) gene, isoform 1 (INVIVO gene), and control plasmid (H2B-RFP). Nine micrograms of Sdf-1 plasmid and $1 \mu \mathrm{g}$ of H2B-RFP plasmid in $50 \mu \mathrm{l}$ of PBS or $10 \mu \mathrm{g}$ of H2B-RFP plasmid in $50 \mu \mathrm{l}$ of PBS were injected into injured muscles. Then, after $24 \mathrm{~h}, \mathrm{CXCR} 4^{+} \mathrm{BMCs}\left(\beta-\mathrm{gal}^{+}\right)$ pretreated by coculturing with myofibers in the presence of Sdf- 1 and control CXCR4 ${ }^{+} \mathrm{BMCs}\left(\beta-\mathrm{gal}^{+}\right)$, in other words freshly isolated from bone marrow and sorted, were transplanted into regenerating and electroporated muscles. Each muscle received 100,000 cells in $50 \mu \mathrm{l}$ of PBS. Next, muscles were analyzed 12 days postinjury (7 days after cells injection and 8 days after plasmid electroporation).

\section{Immunoanalysis of CXCR4 ${ }^{+} B M C s\left(\beta-g a I^{+}\right)$and myofibers}

Selected antigens were immunolocalized in: 1$)$ freshly isolated $\mathrm{CXCR} 4^{+} \mathrm{BMCs}\left(\beta-\mathrm{gal}^{+}\right)$that were incubated for 30 min in DMEM supplemented with 20\% FBS and allowed to attach to cover slides coated with poly-L-lysine; 2) $\mathrm{CXCR} 4^{+} \mathrm{BMCs}\left(\beta-\mathrm{gal}^{+}\right)$that were cultured for $24 \mathrm{~h}$ on Matrigel in DMEM supplemented with 20\% FBS, 10\% HS, $0.5 \% \mathrm{CEE}$, and $1 \%$ penicillin/streptomycin; and 3) single myofibers with attached $\mathrm{CXCR} 4^{+} \mathrm{BMCs}\left(\beta-\mathrm{gal}^{+}\right)$that were cultured for 5 days in hanging drops. The specimens were washed three times in PBS and fixed in 3\% paraformaldehyde in PBS for $10 \mathrm{~min}$. Next, specimens were washed with PBS, permeabilized with $0.05 \%$ Triton X-100 (Sigma-Aldrich) in PBS for $3 \mathrm{~min}$. Additionally, myofibers with attached CXCR4 ${ }^{+} \mathrm{BMCs}\left(\beta-\mathrm{gal}^{+}\right)$were incubated with $15 \mathrm{mM} \mathrm{NH}_{4} \mathrm{Cl}$ for $20 \mathrm{~min}$, followed by incubation with $10 \%$ HS (Life Technologies at room temperature for $30 \mathrm{~min}$. Then, specimens were incubated in $0.25 \%$ glycine (Sigma-Aldrich) in PBS for $20 \mathrm{~min}$, followed by incubation in $3 \%$ bovine serum albumin (BSA) in PBS (Sigma-Aldrich) containing $2 \%$ donkey serum (Sigma-Aldrich) at room temperature for $1 \mathrm{~h}$. Next, specimens were incubated with primary antibodies (anti-CXCR4, Abcam; anti-nestin, Abcam; anti-CD45, Santa Cruz; anti- $\beta$-galactosidase, Abcam; anti-M-cadherin, Abcam; anti-syndecan-4, Abcam; anti-integrin- $\alpha 7$, Abcam; anti-Ki67, 
Abcam; anti-Myf5, Abcam; anti-Myod1, Abcam; and anti-NICD, Cell Signalling) diluted either in 3\% BSA in PBS 1:100 (BMCs) or 5\% HS/PBS 1:50 (myofibers with attached CXCR4 $\left.{ }^{+} \mathrm{BMCs}\left(\beta-\mathrm{gal}^{+}\right)\right)$at $4{ }^{\circ} \mathrm{C}$ overnight, followed by incubation with appropriate secondary antibodies conjugated with Alexa Fluor 488 or 594 (Life Technologies) diluted either in $1.5 \%$ BSA/PBS (1:200) or $5 \%$ HS/PBS (1:100) at room temperature for 1-2 h. Nuclei were visualized with DraQ5 (Biostatus Limited) diluted in PBS (1:1000; specimens were incubated at room temperature for $5 \mathrm{~min}$ ). The specimens were mounted with Fluorescent Mounting Medium (Dako Cytomation). The appropriate controls for secondary antibodies were used. The proportion of cells expressing CXCR4, nestin, or CD45 was counted on slides from 20 fields of view. The proportion of cells expressing M-cadherin, syndecan-4, integrin $\alpha 7$, Myf5, Myod1, Ki67, and NICD was counted on 10 myofibers during each experiment. Each analysis was repeated three times.

\section{Immunoanalysis of muscle sections}

Seven or 21 days after $\mathrm{CXCR} 4^{+} \mathrm{BMCs}\left(\beta-\mathrm{gal}^{+}\right)$transplantation, gastrocnemius or tibialis anterior muscles were isolated and frozen in isopentane cooled with liquid nitrogen, transferred to $-80{ }^{\circ} \mathrm{C}$, cut into $7-\mu \mathrm{m}$ thick sections using a cryomicrotome (Microm HM525NX), and processed for immunolocalization of selected antigens. Muscle sections were hydrated in PBS and fixed in 3\% paraformaldehyde for $10 \mathrm{~min}$. Next, samples were washed with PBS, permeabilized with $0.05 \%$ Triton X-100 (Sigma-Aldrich) in PBS, incubated in $0.25 \%$ glycine (Sigma-Aldrich) in PBS, followed by incubation in $3 \%$ BSA in PBS (Sigma-Aldrich) containing 2\% donkey serum (Sigma-Aldrich) at room temperature for $1 \mathrm{~h}$. Next, all samples were incubated with primary antibodies (anti- $\beta$-galactosidase, Abcam; and anti-laminin, Sigma Aldrich) diluted in 3\% BSA in PBS (1:100) at $4{ }^{\circ} \mathrm{C}$ overnight, followed by incubation with secondary antibodies conjugated with Alexa Fluor 488 or 594 (Life Technologies) diluted in 1.5\% BSA/PBS (1:200) at room temperature for $2 \mathrm{~h}$. Nuclei were visualized with DraQ5 (Biostatus Limited) diluted in PBS (1:1000; samples were incubated at room temperature for $5 \mathrm{~min}$ ). Samples were mounted with Fluorescent Mounting Medium (Dako Cytomation). The newly formed myofibers with centrally located nuclei were counted 7 days after cell administration. The number of all myofibers was counted 21 days after cells administration. Ten fields of view from 10 muscles were analyzed for each experiment.

\section{Enzyme-linked immunosorbent assay (ELISA)}

Tibialis anterior muscles transfected either with control plasmid (H2B-RFP) or the that encoding Sdf-1 were isolated 12 days following injury (i.e. 7 days after cell injection and 8 days after plasmid electroporation). Muscles were homogenized in cOmplete $^{\mathrm{Tm}}$ Lysis-M EDTA-free (Roche). Sdf-1 level were measured using ELISA (R\&D) according to the manufacturer's protocol. The assay was conducted using a $\mu$ Quant instrument (Biotek Instruments).

\section{Statistical analysis}

Data are presented as mean \pm standard deviation. Student's $t$ test was used for statistical analyses to compare each condition against the control, and $p<0.05$ was considered significant.

\section{Results}

\section{BMCs can colonize the satellite cell niche in vitro}

First, we isolated and characterized the CXCR4 ${ }^{+} \mathrm{BMCs}$ and showed that a significant proportion of these cells expressed nestin $(32.8 \pm 2.8 \%)$ and only a small fraction expressed CD45 (7.9 $\pm 1.4 \%)$ (Fig. 1a). On the basis of nestin expression, we concluded that the $\mathrm{CXCR} 4^{+} \mathrm{BMC}$ population contained a high percentage of BM-MSCs, that is cells that fulfill the criteria for multipotent mesenchymal stem cells [47].

To test whether CXCR4 ${ }^{+}$BMCs are able to colonize the satellite cell niche we isolated them from the bone marrow of mice expressing $\beta$-galactosidase $\left(\beta\right.$-gal $\left.{ }^{+}\right)$and cocultured in hanging drops of medium with myofibers isolated from muscles of wild-type mice (Fig. 1b). As shown previously, the myofiber culture in the hanging drops allows the satellite cells to interact with their niche for a prolonged time and prevents their activation in vitro [45]. Thus, we assumed that such a culture method might be suitable to study the interactions of stem cells with myofibers and satellite cell niche. The expression of $\beta$-galactosidase allowed us to distinguish CXCR4 ${ }^{+} \mathrm{BMCs}\left(\beta-\mathrm{gal}^{+}\right)$from wild-type satellite cells connected with myofibers. Moreover, myofibers and cells were cultured in the presence or absence of Sdf-1. Such an approach allowed us to define the influence of Sdf-1 on the ability of $\mathrm{CXCR} 4^{+} \mathrm{BMCs}\left(\beta-\mathrm{gal}^{+}\right)$to colonize the satellite cell niche.

After 5 days of coculture, CXCR4 ${ }^{+} \mathrm{BMCs}\left(\beta-\right.$ gal $\left.^{+}\right)$were able to bind to the myofibers and this ability dramatically increased in the presence of Sdf-1 (Fig. 2a, b). At the same time, $\mathrm{CXCR} 4^{+} \mathrm{BMCs}\left(\beta-\mathrm{gal}^{+}\right)$that attached to the myofibers started to express the adhesion proteins M-cadherin, syndecan-4, and integrin $\alpha 7$ characteristic for satellite cells (Fig. 2c, d). The proportion of $\beta$-gal ${ }^{+}$ cells expressing integrin $\alpha 7$ differed between each analyzed fiber and varied from $10 \%$ to $100 \%$.

To show that expression of adhesion proteins resulted from cell interaction with the myofiber we analyzed freshly isolated $\mathrm{CXCR} 4^{+} \mathrm{BMCs}\left(\beta-\mathrm{gal}^{+}\right)$(Fig. 2e) as well as those that were in-vitro cultured on Matrigel for $24 \mathrm{~h}$ 


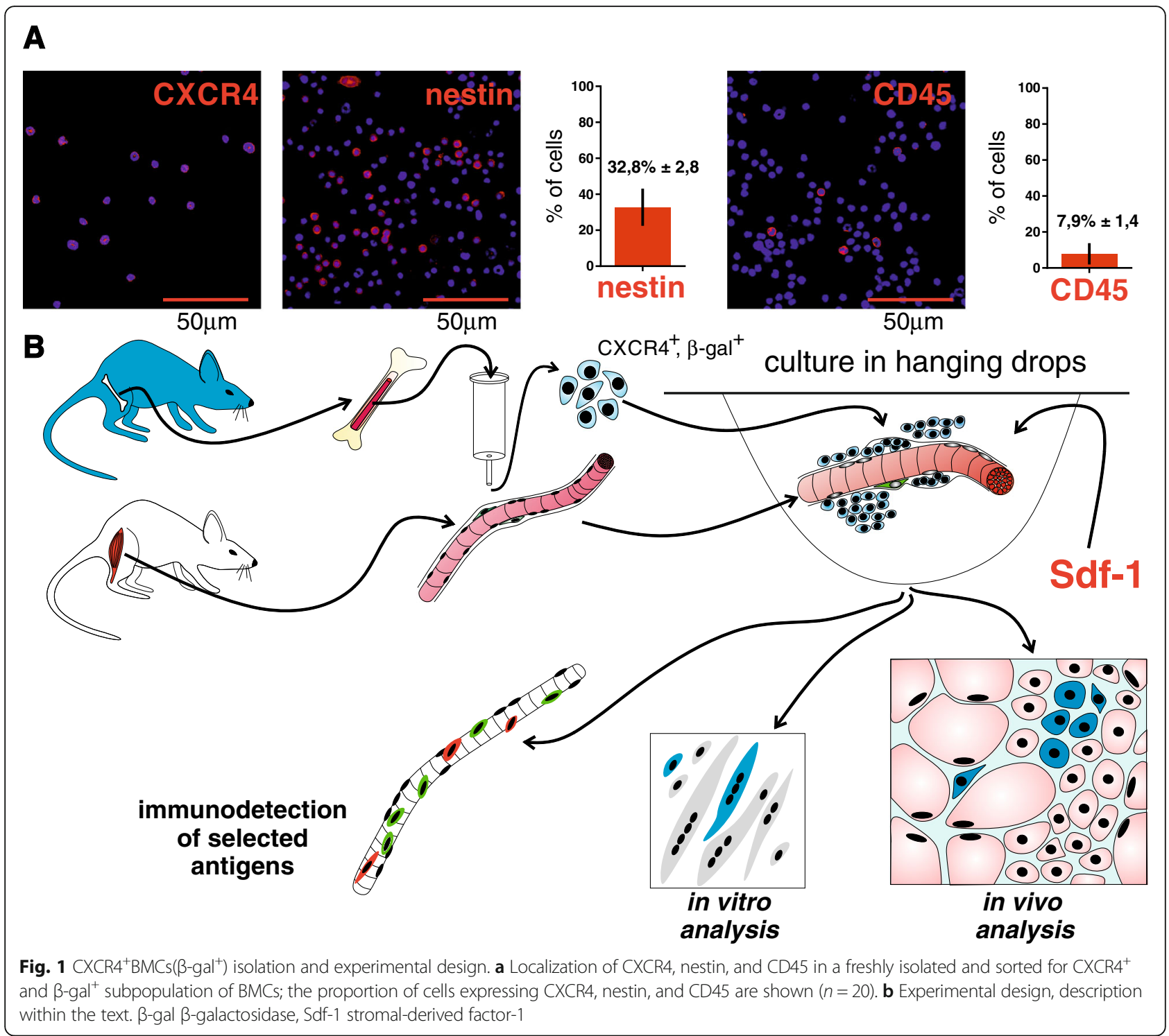

(Fig. 2f). Both types of cells did not express M-cadherin and syndecan-4, but some of them expressed integrin $\alpha 7$ (Fig. 2e, f). We showed previously that Sdf-1 did not change the expression of adhesion proteins, except for CD9 [40]. Thus, we concluded that interaction of CXCR4 ${ }^{+} \mathrm{BMCs}\left(\beta-\mathrm{gal}^{+}\right)$with myofibers induced the expression of adhesion proteins characteristic for satellite cells. Moreover, Sdf-1 significantly increased the number of $\mathrm{CXCR} 4^{+} \mathrm{BMCs}\left(\beta-\mathrm{gal}^{+}\right)$able to bind myofibers.

Interaction of $\mathrm{CXCR} 4^{+} \mathrm{BMCs}\left(\beta-\mathrm{gal}^{+}\right)$with myofibers induces their myogenic differentiation and leads to Notch activation Knowing that in-vitro cultured $\mathrm{CXCR} 4^{+} \mathrm{BMCs}\left(\beta-\mathrm{gal}^{+}\right)$can interact with myofibers, we tested whether these cells could initiate a myogenic program. After 5 days of coculture, $47.7 \%$ of $\mathrm{CXCR}^{+} \mathrm{BMCs}\left(\beta-\mathrm{gal}^{+}\right)$associated with myofibers expressed Ki67 (in other words they proliferated; Fig. 3a, b). As we have previously documented, Sdf-1 did not influence proliferation of cells [48]. After 5 days of coculture, $56.7 \%$ of $\mathrm{CXCR}^{+} \mathrm{BMCs}\left(\beta-\mathrm{gal}^{+}\right)$expressed Myf5 and $83 \%$ expressed Myod1 (Fig. 3c, d). Thus, the large proportion of $\mathrm{CXCR} 4{ }^{+} \mathrm{BMCs}\left(\beta-\mathrm{gal}^{+}\right)$underwent a myogenic commitment as the result of their interaction with myofibers. Sdf-1 did not impact the expression of Myf5 and Myod1. Thus, Sdf-1 stimulated binding of $\mathrm{CXCR} 4^{+} \mathrm{BMCs}\left(\beta-\mathrm{gal}^{+}\right)$ to myofibers but did not change the proportion of cells expressing MRFs. Thus, we showed that our model allows induced expression of MRFs in CXCR4 $4^{+} \mathrm{BMCs}\left(\beta-\mathrm{gal}^{+}\right)$. Next, we showed that $\mathrm{CXCR} 4^{+} \mathrm{BMCs}\left(\beta-\mathrm{gal}^{+}\right)$binding to myofiber was accompanied by activation of the Notch pathway. After 5 days of coculture, over $60 \%$ of $\mathrm{CXCR} 4^{+} \mathrm{BMCs}\left(\beta-\mathrm{gal}^{+}\right)$ presented nuclear localization of NICD, the active intracellular Notch domain released after its activation (Fig. 3e-g). 


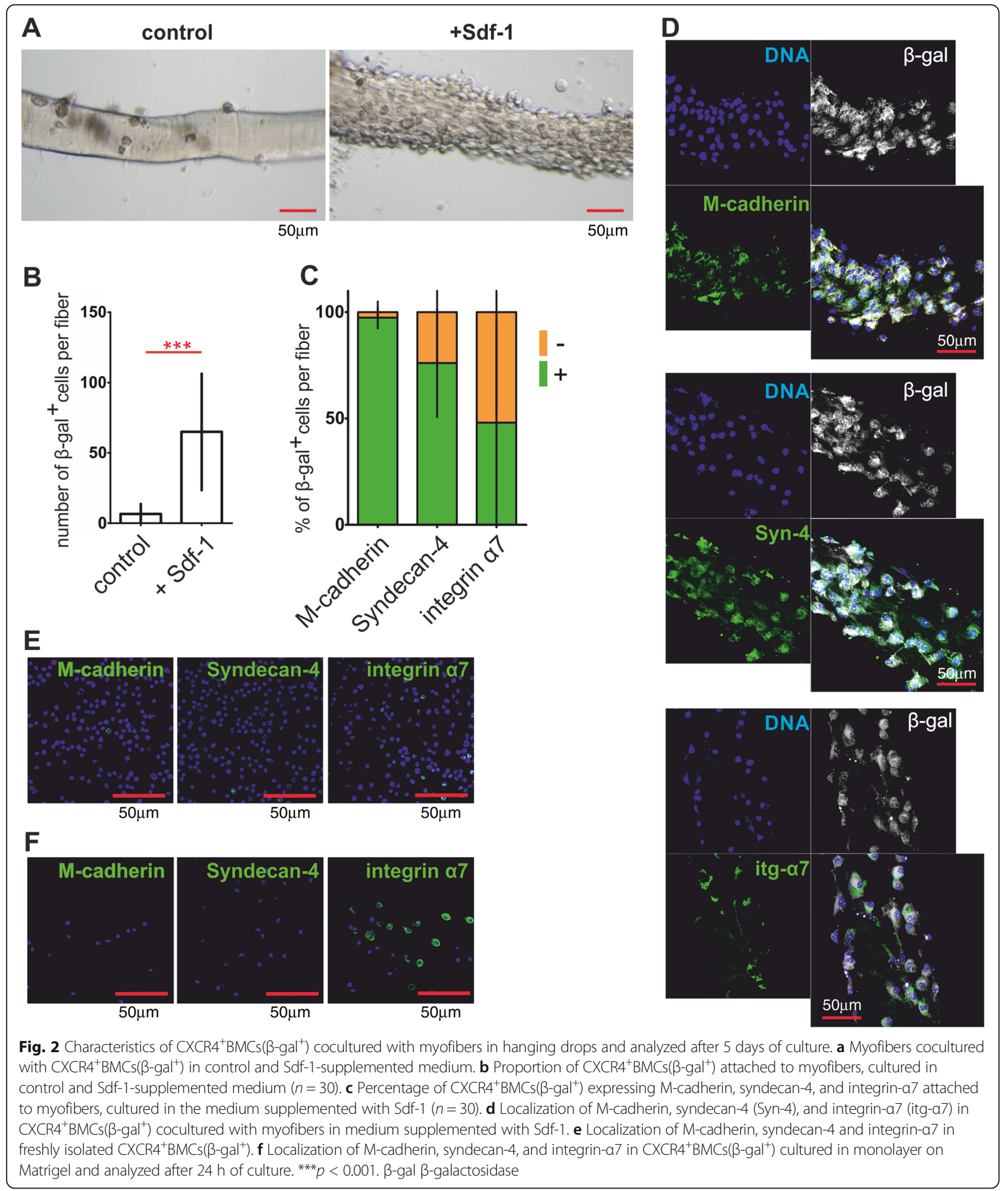

Importantly, only $10.2 \pm 1.6 \%$ of freshly isolated CXCR4 ${ }^{+} \mathrm{BMCs}\left(\beta-\mathrm{gal}^{+}\right)$showed such localization of NICD (Fig. 3e-g). Thus, we conclude that binding of CXCR4 ${ }^{+} \mathrm{BMCs}\left(\beta-\mathrm{gal}^{+}\right)$to myofibers results in activation of the Notch signaling pathway.
After 5 days of coculture in hanging drops myofibers with associated $\mathrm{CXCR} 4^{+} \mathrm{BMCs}\left(\beta-\mathrm{gal}^{+}\right)$were transferred into monolayer culture on Matrigel. After 2-3 days of such culture satellite cells that were associated with myofibers as well as $\mathrm{CXCR} 4^{+} \mathrm{BMCs}\left(\beta-\mathrm{gal}^{+}\right)$that 
A

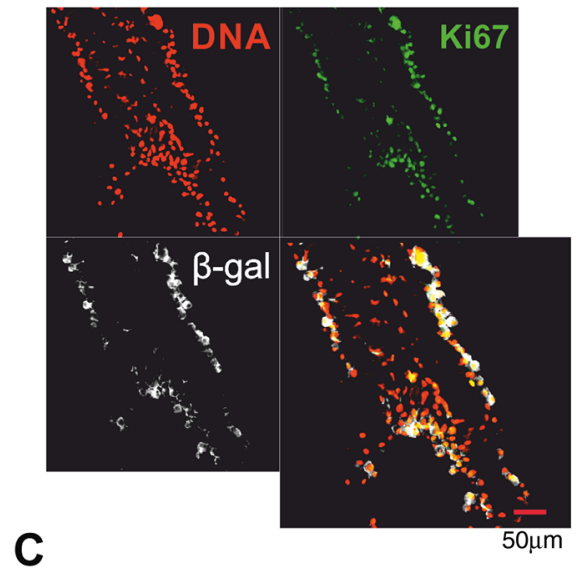

C

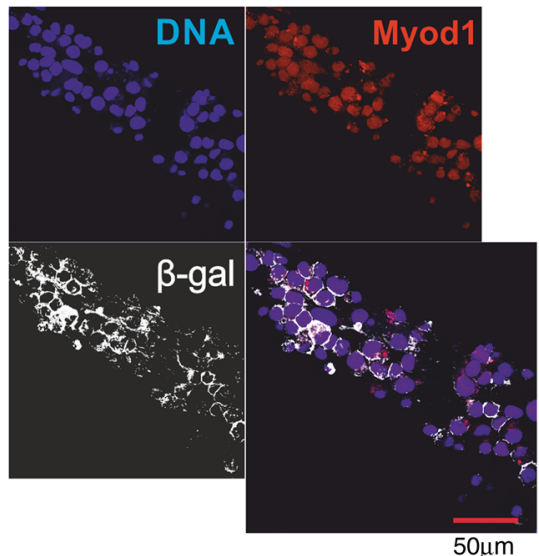

B
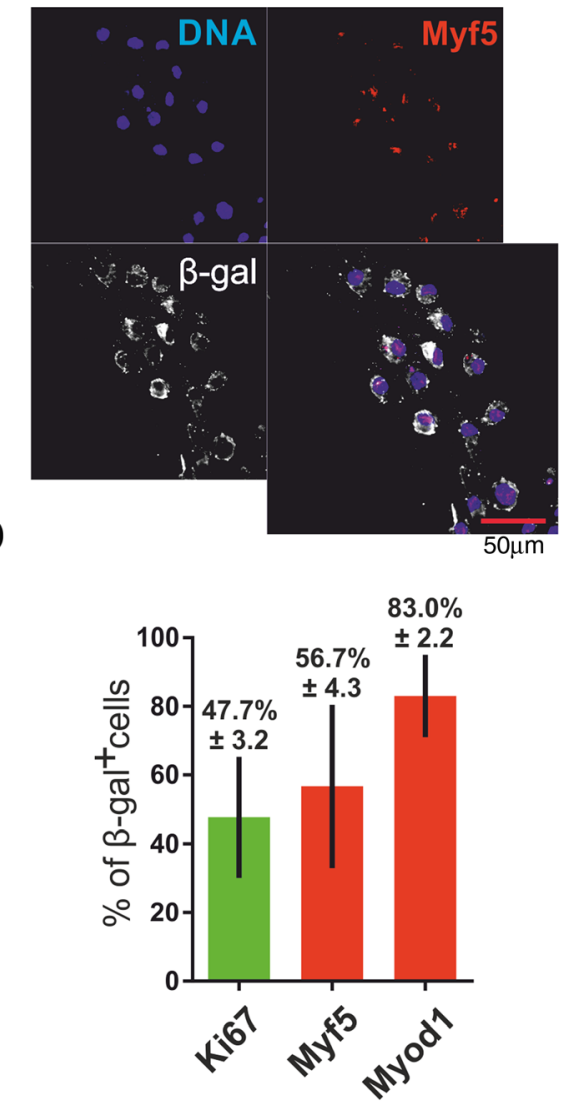

G
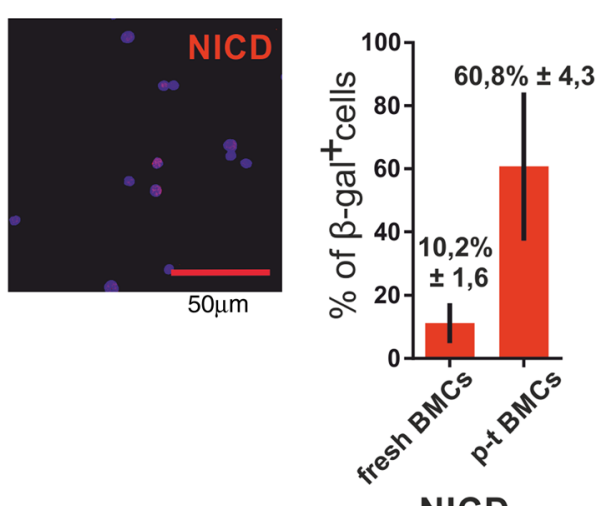

Fig. 3 Expression of myogenic regulatory factors, Ki67, and NICD in CXCR4 ${ }^{+} B M C s\left(\beta-\left.g a\right|^{+}\right)$cocultured with myofibers for 5 days. a Localization of Ki67. b Localization of Myf5. c Localization of Myod1. d Percentage of CXCR4 ${ }^{+} B M C s\left(\beta-g a l^{+}\right)$expressing Ki67, Myf5, and Myod1 attached to myofibers $(n=30)$. e Localization of Notch intracellular domain (NICD). $\mathbf{f}$ Localization of NICD in freshly isolated CXCR4 ${ }^{+} B M C s\left(\beta-g a l^{+}\right)$. $\mathbf{g}$ Percentage of CXCR4 ${ }^{+} B M C s\left(\beta-\left.g a\right|^{+}\right)$expressing NICD among cells freshly isolated from bone marrow-derived cells (fresh BMCs; $n=20$ ) and after coculture with myofibers ( $p$-t BMCs; $n=30$ ). $\beta$-gal $\beta$-galactosidase

colonized the satellite cell niche migrated from the surface of the myofibers and started to differentiate (Fig. 4). By detecting active $\beta$-galactosidase we were able to identify myotubes resulting from the fusion of cells derived from $\mathrm{CXCR} 4^{+} \mathrm{BMCs}\left(\beta\right.$-gal $\left.^{+}\right)$and satellite cells (Fig. 4).
Thus, we showed that CXCR4 ${ }^{+} \mathrm{BMCs}\left(\beta-\mathrm{gal}^{+}\right)$, pretreated by culture on myofibers, could effectively fuse and form myotubes. Importantly, CXCR4 ${ }^{+} \mathrm{BMCs}\left(\beta\right.$-gal $\left.{ }^{+}\right)$that were freshly isolated from bone marrow did not fuse with each other or spontaneously form myotubes (Fig. 4). 


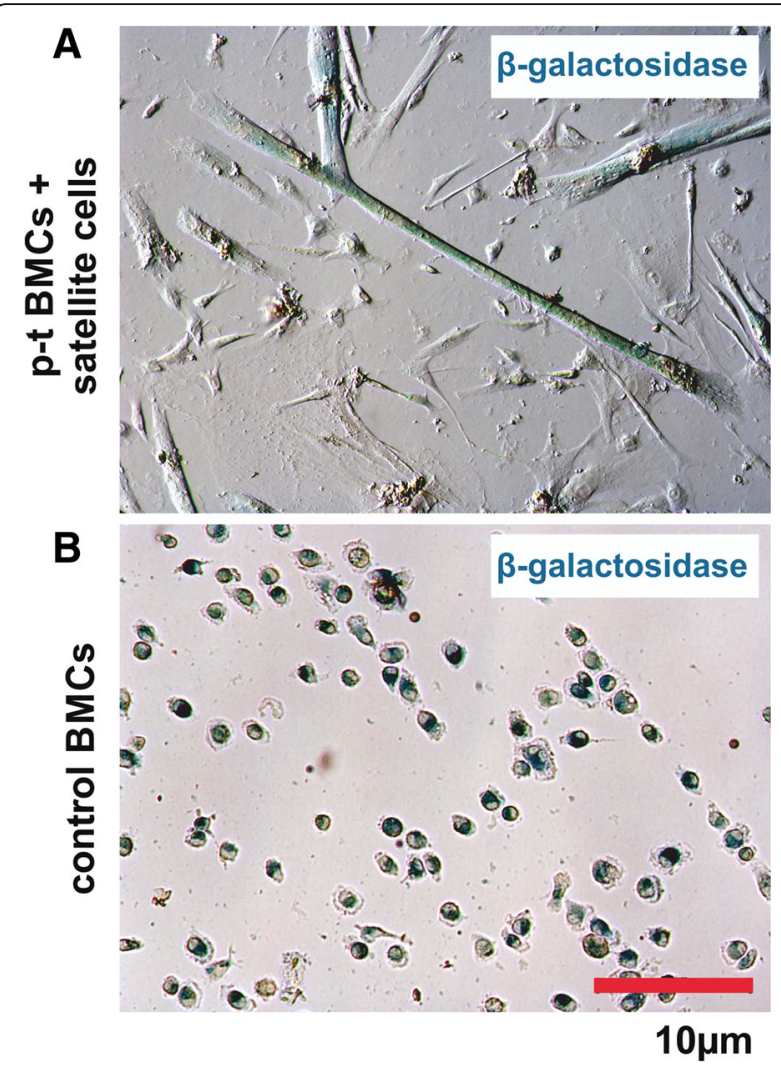

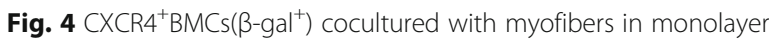
on Matrigel. a CXCR4 ${ }^{+} B M C s\left(\beta-g a l^{+}\right)$cocultured with myofibers in the presence of $S d f-1$ for 5 days and transferred on Matrigel and cultured for 14 days. b Freshly isolated $C X C R 4^{+} B M C s\left(\beta-\right.$ gal $\left.{ }^{+}\right)$cultured on Matrigel for 7 days. BMC bone marrow-derived cell, $\mathrm{p}$-t pretreated

We also examined whether cells other than the CXCR4 ${ }^{+} \mathrm{BMCs}\left(\beta-\mathrm{gal}^{+}\right)$can attach to myofibers and initiate a myogenic program. Thus, $\beta-$ gal $^{+}$fibroblasts were cocultured with myofibers under the same conditions as those used for $\mathrm{CXCR} 4^{+} \mathrm{BMCs}\left(\beta-\mathrm{gal}^{+}\right)$, including Sdf-1 treatment. The fibroblasts proliferated, as documented by the presence of Ki67 (Fig. 5a), but only a small proportion of them was able to bind to myofibers and colonize the satellite cell niche. Importantly, under such culture conditions, these cells never expressed MFRs (i.e., Myf5) or M-cadherin (Fig. 5a). Moreover, in monolayer culture on Matrigel where fibroblasts were released from myofibers, no multinucleated myotubes with active $\beta$-galactosidase was observed (Fig. 5b). Thus, we conclude that coculture with myofibers did not induce myogenic differentiation of fibroblasts.

CXCR4 ${ }^{+} \mathrm{BMCs}\left(\beta-\mathrm{gal}^{+}\right)$pretreated by coculture on myofibers efficiently participate in skeletal muscle regeneration

Since coculture with myofibers induces a myogenic identity of $\mathrm{CXCR} 4^{+} \mathrm{BMCs}\left(\beta-\mathrm{gal}^{+}\right)$, we tested whether these cells possess increased ability to participate in skeletal muscle regeneration in vivo. Skeletal muscles of wild-type mice were injured with ctx and injected with CXCR4 ${ }^{+} \mathrm{BMCs}\left(\beta-\mathrm{gal}^{+}\right) 3$ days after injury. Two types of BMCs were tested: control CXCR4 ${ }^{+} \mathrm{BMCs}\left(\beta-\right.$ gal $\left.^{+}\right)$freshly isolated from bone marrow, and those pretreated by 5 days coculture with myofibers in the presence of Sdf- 1 . Regenerated muscles were analyzed 7 and 21 days after cell administration (Fig. 6). $\mathrm{CXCR} 4^{+} \mathrm{BMCs}\left(\beta-\mathrm{gal}^{+}\right)$were detected using immunolocalization of $\beta$-galactosidase. Control CXCR4 ${ }^{+} \mathrm{BMCs}\left(\beta-\mathrm{gal}^{+}\right)$participated in the formation of new myofibers with very low efficiency. Seven days after cell administration, only $0.4 \pm 0.1 \%$ of new myofibers with centrally located nuclei expressed $\beta$-galactosidase (Fig. 6a, b). Twenty-one days after administration of cells, this proportion was even lower and had dropped to $0.07 \pm 0.3 \%$ (Fig. 6a, c). Seven days after injection of $\operatorname{CXCR} 4^{+} \mathrm{BMCs}\left(\beta-\mathrm{gal}^{+}\right)$ pretreated by coculture with myofibers in the presence of Sdf-1, $3.41 \pm 0.7 \%$ of newly formed myofibers expressed $\beta$-galactosidase, and at day 21 as many as $1.4 \pm 0.2 \%$ of all myofibers expressed $\beta$-galactosidase (Fig. 6a, b, c). Thus, after 7 and 21 days following cell administration, pretreated $\mathrm{CXCR} 4{ }^{+} \mathrm{BMCs}\left(\beta-\mathrm{gal}^{+}\right)$resulted in the formation of 8.5- and 20-times more myofibers, respectively, compared with control cells (Fig. 6b, c). Thus, we have shown that coculture of $\mathrm{CXCR} 4^{+} \mathrm{BMCs}\left(\beta-\mathrm{gal}^{+}\right)$with myofibers increased their ability to participate in skeletal muscle regeneration. Interestingly, in muscles that received control $\mathrm{CXCR} 4^{+} \mathrm{BMCs}\left(\beta-\mathrm{gal}^{+}\right)$, i.e., those freshly isolated from bone marrow, we observed numerous adipose cells, as shown by Oil Red $\mathrm{O}$ staining of skeletal muscles analyzed after 21 days following cells administration (Fig. 6d). This effect was observed in 4 out of 10 muscles analyzed. Importantly, we did not observe adipose cells accumulation in any of the 10 analyzed muscles injected with the $\mathrm{CXCR} 4^{+} \mathrm{BMCs}\left(\beta-\mathrm{gal}^{+}\right)$that were pretreated by coculture with myofibers.

To improve the homing of $\mathrm{CXCR} 4^{+} \mathrm{BMCs}\left(\beta-\mathrm{gal}^{+}\right)$, we overexpressed Sdf-1 in regenerating muscle using an in-vivo electroporation system. Previously, we have shown that Sdf-1 injection improved skeletal muscle regeneration and stem cell mobilization $[49,50]$. We also documented that pretreatment of cells with Sdf- 1 induced migration of these cells after their transplantation into regenerating muscles [48]. Here, we tested whether the overexpression of Sdf-1 in injured and regenerating muscles would improve colonization of this tissue with transplanted cells. Thus, at day 4 of regeneration induced by ctx injection, muscles were electroporated either with control plasmid or with plasmid encoding Sdf-1 (Fig. 7). Twenty-four hours later the $\operatorname{CXCR} 4^{+} \mathrm{BMCs}\left(\beta-\right.$ gal $\left.^{+}\right)$ were injected into the regenerating muscles. Introduction of Sdf-1-encoding plasmid resulted in a significant Sdf-1 increase within the muscle tissue (Fig. 7b). Twelve days postinjury (i.e., 7 days after cell injection and 8 days after electroporation), we localized 

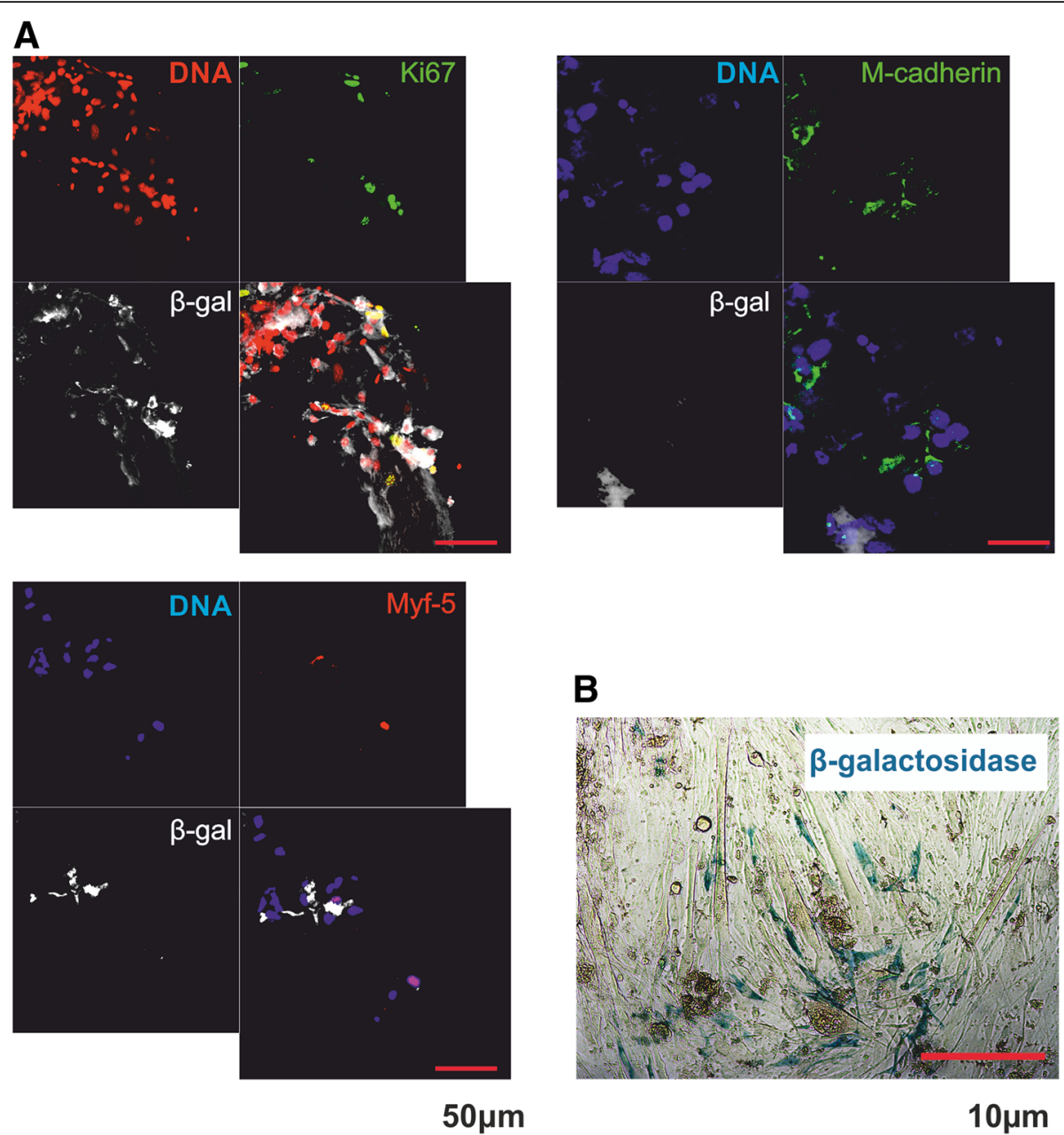

Fig. 5 Analysis of $\beta$-gal ${ }^{+}$fibroblasts cocultured with myofibers in hanging drops and transferred to monolayer on Matrigel. a Localization of Myf5, M-cadherin, and Ki67 in $\beta$-gal ${ }^{+}$fibroblasts cocultured for 5 days with myofibers in hanging drops in medium supplemented with Sdf-1. b $\beta$-gal ${ }^{+}$ fibroblasts cocultured for 5 days with myofibers in hanging drops in medium supplemented with Sdf- 1 and then transferred to monolayer culture on Matrigel and cultured for 14 days. $\beta$-gal $\beta$-galactosidase

transplanted $\mathrm{CXCR} 4{ }^{+} \mathrm{BMCs}\left(\beta-\mathrm{gal}^{+}\right)$. Control cells, in other words freshly isolated $\mathrm{CXCR} 4^{+} \mathrm{BMCs}\left(\beta-\mathrm{gal}^{+}\right)$, were mostly found between myofibers and within connective tissue. Only some of them participated in the formation of myofibers (Fig. 7a, c). Transplantation of CXCR4 ${ }^{+} \mathrm{BMCs}\left(\beta-\mathrm{gal}^{+}\right)$that were pretreated by coculture with muscle fibers into electroporated muscles resulted in more abundant participation of these cells in the formation of new myofibers (Fig. 7a, c). Moreover, pretreated CXCR4 ${ }^{+} \mathrm{BMCs}\left(\beta-\mathrm{gal}^{+}\right)$formed more new myofibers in Sdf-1-overexpressing muscles. However, the difference between the muscles electroporated with control and Sdf-1-encoding plasmid was not statistically significant (Fig. 7c). Thus, we demonstrated that coculture of $\mathrm{CXCR} 4^{+} \mathrm{BMCs}\left(\beta-\mathrm{gal}^{+}\right)$with myofibers increased their ability to participate in skeletal muscle regeneration, and that Sdf-1 overexpression in muscles could support this process.

\section{Discussion}

In our previous studies, we showed that Sdf- 1 treatment allows skeletal muscle regeneration improvement via the mobilization of cells expressing CXCR4 and CD34 [49]. Importantly, the improvement of skeletal muscle regeneration stimulated by $\mathrm{Sdf}-1$ and granulocyte colony-stimulating factor (G-CSF) was observed also in Pax $7^{-1-}$ mice (i.e., mice lacking satellite cells), suggesting that stem cells other than satellite cells could be mobilized to injured muscles [50]. We also documented that Sdf-1 treatment of cells, such as satellite cell-derived myoblasts, CXCR $4^{+} \mathrm{BMCs}$, or embryonic stem cells, increased expression of tetraspanin CD9 that is crucial for myoblast adhesion and fusion [40]. As a result, Sdf-1-treated CXCR4 ${ }^{+}$BMCs or embryonic stem cells fused more efficiently with myoblasts. Sdf-1 also altered cell migration and actin organization via focal adhesion kinase (FAK), cell division control protein 42 (Cdc42), and Ras-related 

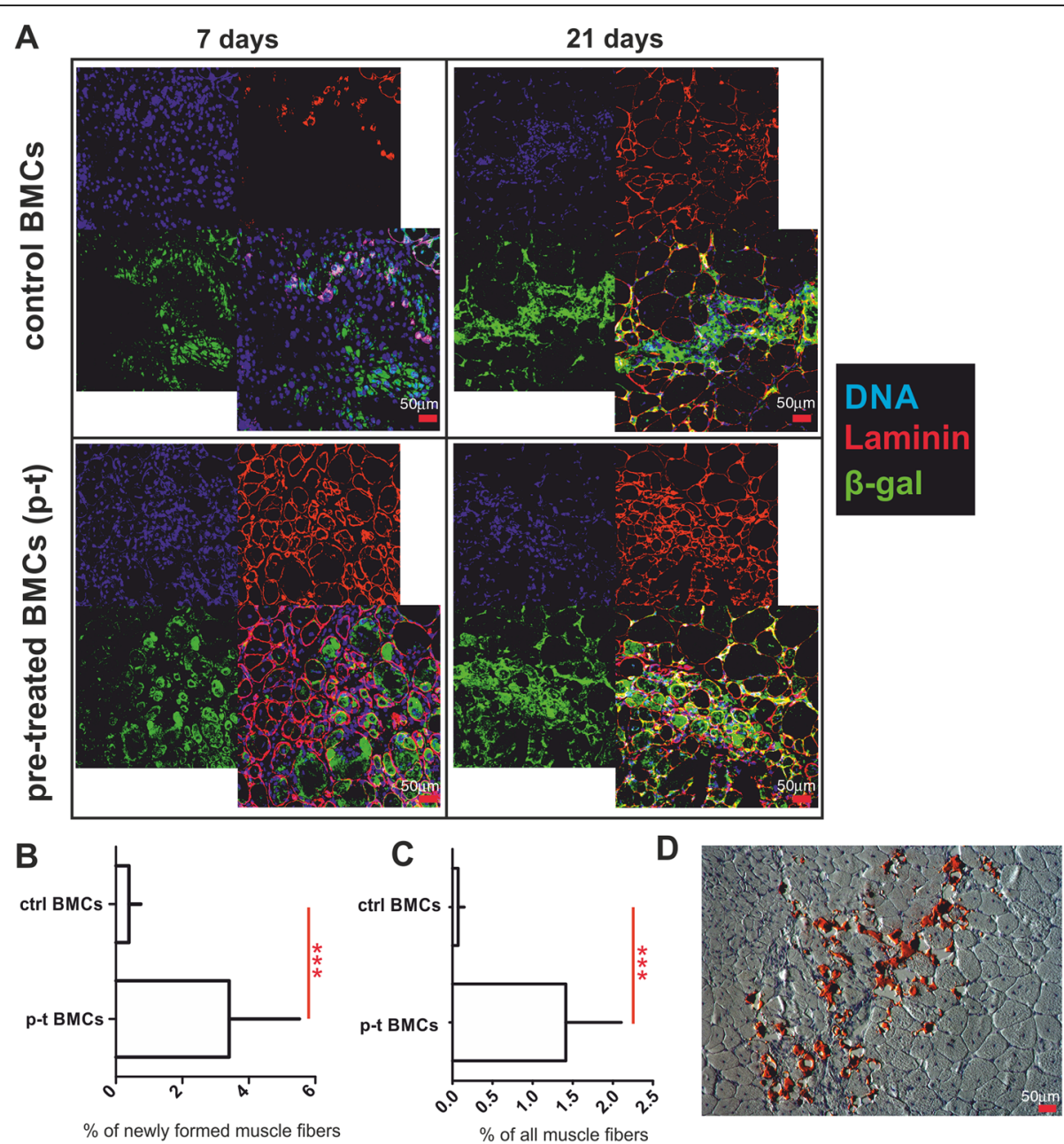

Fig. 6 Analysis of regenerating muscles to which $C X C R 4^{+} B M C s\left(\beta-\left.g a\right|^{+}\right)$were transplanted. a Localization of control, freshly isolated and sorted CXCR4 ${ }^{+} B M C s\left(\beta-g a l^{+}\right)(c t r l)$ and those pretreated (p-t) by coculture for 5 days in the presence of Sdf- 1 with myofibers $C X C R 4^{+} B M C s\left(\beta-g a l^{+}\right)$in regenerating muscle after 7 and 21 days after cell administration. b Percentage of newly formed myofibers after 7 days and $\mathbf{c}$ of all myofibers expressing $\beta$-galactosidase after 21 days after cell administration $(n=10)$. $\mathbf{d}$ Oil Red $O$ staining of adipocytes present in muscle sections after control CXCR4 ${ }^{+}$BMCs $\left(\beta-\right.$ gal $\left.{ }^{+}\right)$administration to regenerating muscle. ${ }^{* *} p<0.001$. $\beta$-gal $\beta$-galactosidase

C3 botulinum toxin substrate (Rac-1), as well as matrix metalloproteinase (MMP) activity [48, 49]. Currently, using a new in-vitro model, we were able to test the influence of the satellite cell niche on the differentiation of bone marrow-derived cells. We have shown that coculture of stem cells with myofibers could be used as a tool to study in-vitro interactions of exogenous stem cells with the satellite cell niche. Using a hanging drop coculture system, we showed that CXCR4 ${ }^{+}$BMCs were able to colonize the satellite cell niche. Importantly, CXCR4 ${ }^{+}$BMCs interacting with myofibers adopt a myogenic identity manifested by expression of MRFs and adhesion proteins characteristic of satellite cells, the ability to fuse with myoblasts, and to participate in skeletal muscle reconstruction. Sdf-1 treatment significantly increased this process. It has been documented previously that culture of myofibers in a hanging drop allowed satellite cells to retain their properties for prolonged time [45]. Such satellite cells maintained Pax7 expression as a result of their interactions with the niche [45]. Our results strongly suggest that the myofiber-specific niche can also influence cells other than satellite cells. We suggest that interaction with the satellite cell niche is an important step towards facilitating myogenic commitment of nonmyogenic cells.

The population of BMCs contains BM-MSCs that share the general features of other populations of MSCs and, importantly, meet the rigorous criteria of being multipotent stem cells: the ability to self-renew and to give rise to multilineage differentiation in vitro and in vivo [3]. In our study, we showed that a substantial proportion of the CXCR4 ${ }^{+}$BMC population expressed nestin which is a marker of BM-MSCs [47], and only a small proportion of 

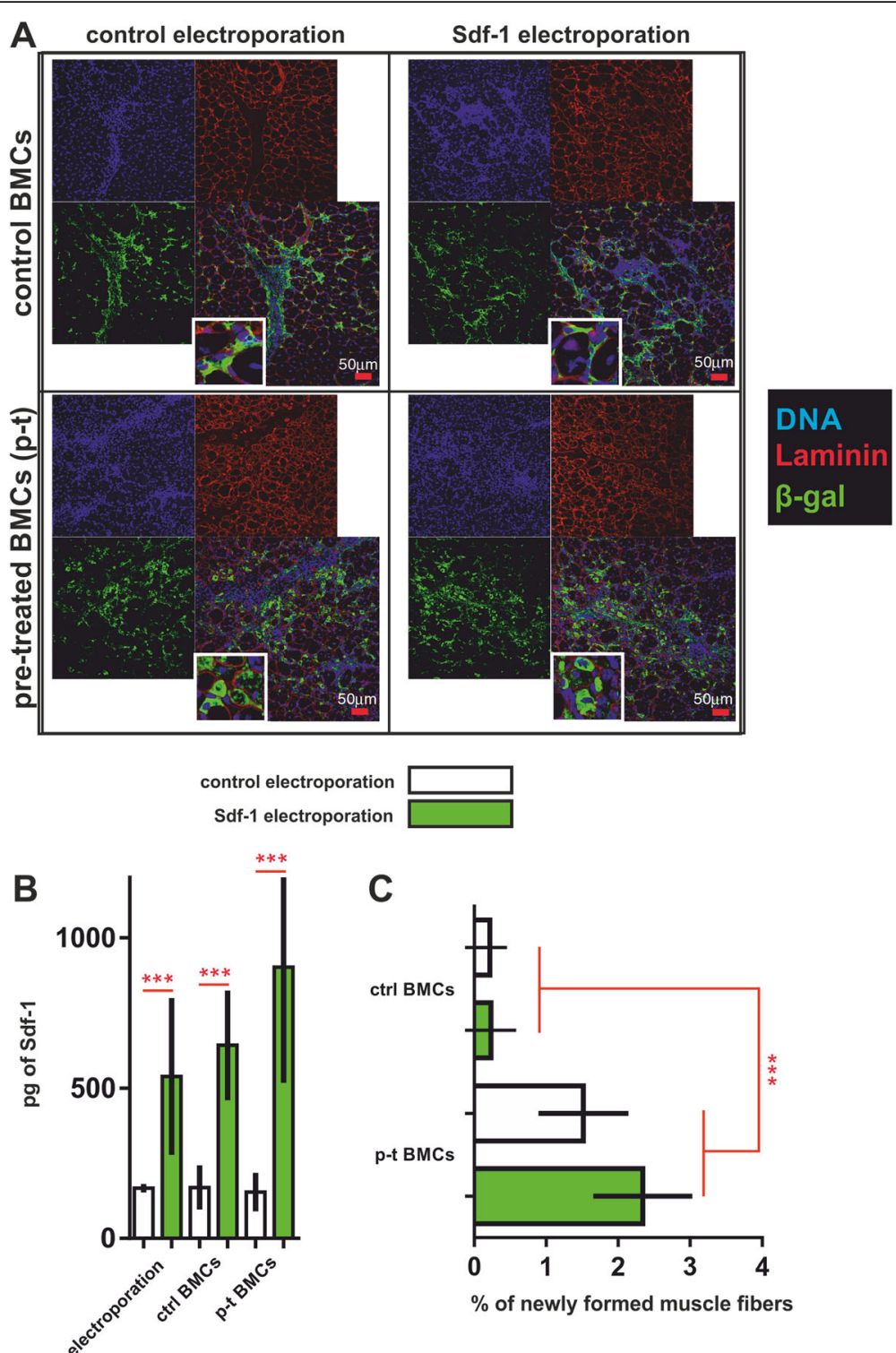

Fig. 7 Analysis of regenerating muscles electroporated with either control plasmid (H2B-RFP) or plasmid coding Sdf-1 to which CXCR4 ${ }^{+} B M C s\left(\beta-g a l^{+}\right)$were transplanted. Muscles were analyzed 12 days after injury, i.e., 7 days after cell injection and 8 days following electroporation. a Localization of transplanted cells; control, freshly isolated and sorted CXCR4 ${ }^{+} B M C s\left(\beta-g a l^{+}\right)$(ctrl) or pretreated (p-t) by coculture for 5 days in the presence of Sdf- 1 with myofibers $C X C R 4^{+} B M C s\left(\beta-g a l^{+}\right)$in regenerating muscle. $\mathbf{b}$ ELISA assessed Sdf- 1 levels in skeletal muscles electroporated either with control or plasmid encoding Sdf-1 $(n=6)$. c Percentage of myofibers with the participation of CXCR4 ${ }^{+} B M C s\left(\beta-g a l^{+}\right)$transplanted into muscles electroporated either with control or plasmid encoding Sdf-1 $(n=6) .{ }^{* * *} p<0.001$. $\beta$-gal $\beta$-galactosidase, BMC bone marrow-derived cell

the CXCR4 ${ }^{+}$BMCs were hematopoietic cells expressing CD45. Mouse BMCs expressing nestin are considered to be the "pure" population of BM-MSCs and fulfill all criteria for stem cells such as BM-MSCs [47] in that they are able to form colonies in in-vitro culture, undergo osteoblastic, adipogenic, and chondrocytic differentiation in vitro, and self-renew and expand after their serial transplantation. Furthermore, mouse BM-MSCs expressing nestin showed perivascular distribution in the bone marrow and colocalization with HSCs [47].
The ability of BM-MSCs to adopt a myogenic fate is still a matter of debate. It was clearly shown by Sacchetti and coworkers that human CD146 ${ }^{+} \mathrm{BM}$-MSCs are not able to undergo myogenic differentiation when transplanted into heterotopic sites or cultured in so-called differentiating medium, (i.e., in the presence of horse serum) [11]. Thus, CD146 ${ }^{+} \mathrm{BM}-\mathrm{MSC}$ do not present a naive myogenic potential. Nevertheless, it is possible to induce the myogenic engagement of BM-MSCs (i.e., to reprogram them). Acquisition of the myogenic identity 
of the BMC adherent fraction could be induced in vitro by a DNA demethylating drug, for example 5-azacytidine [51]. However, human BM-MSCs very rarely form hybrid myotubes in coculture with $\mathrm{C} 2 \mathrm{C} 12$ myoblasts (the proportion of hybrid myotubes was less than $0.038 \%$ ) [11, 21]. Moreover, adherent rat BMCs constitutively expressing active $\beta$-catenin were able to fuse and form myotubes (fusion index of 27.1\%) and expressed Pax7, Myod1, Myf5, myogenin, and $\mathrm{MHC}$, as well as desmin, when cultured in the presence of $2 \%$ horse serum [13]. Pax3 overexpression in human and mouse adherent BMCs induced MRF expression and, as a result, these cells were able to fuse in the presence of horse serum $[14,52]$.

We showed here that activation of the Notch signaling pathway, manifested by nuclear localization of NICD, occurred in CXCR4 ${ }^{+}$BMCs interacting with myofibers. Notch signaling is one of the major regulatory pathways that defines cell fate in relation to neighboring cells [35, 53]. As a result of $\mathrm{CXCR} 4^{+} \mathrm{BMC}$ and myofiber interaction, these cells became competent to activate expression of MRFs. Notch signaling was also shown to regulate the myogenic potential of human and mouse mesoangioblasts which upregulated Notch at early stages of myogenic differentiation [54]. Decreased NICD levels caused by Notch1 and Dll1 knockdown resulted in impaired human and murine mesoangioblast myogenic differentiation and skeletal muscle engraftment after transplantation [54]. Dezawa and coworkers showed that overexpression of NICD and culture in horse serum induces myogenic differentiation of human and rat adherent BMCs resulting in their in-vitro and in-vivo participation in myofiber formation [12]. These cells expressed Pax7, Myod1, and myogenin, and importantly, fused with each other without the requirement for exogenous myoblasts [12]. Thus, the role of Notch signaling could differ between satellite cells and other cell types. Quiescent satellite cells express Notch-1, -2, and -3 , and present high canonical Notch activity and the myofiber is the most likely source of Notch ligands [32, 33, 35]. Notch signaling inhibited pp38 and Myod1, early markers of activated satellite cells, and is silenced before the first satellite cell division $[35,55,56]$. Notch activation upregulates $\operatorname{Pax} 7$ and promotes the self-renewal of skeletal muscle satellite cells [57, 58]. Moreover, satellite cells or myoblasts cultured in the presence of Notch ligands exhibit a muscle stem-like state (i.e., high Pax7 and low Myod1 expression); however, their regenerative ability was lower than that of freshly isolated cells [53].

In our experimental model, CXCR4 ${ }^{+}$BMCs cocultured with myofibers not only activated Notch but also increased the expression of adhesion proteins characteristic of satellite cells and MRFs characteristic of myoblasts. Importantly, such CXCR4 ${ }^{+} \mathrm{BMCs}$ were functional, in other words they were able to fuse with myoblasts in vitro and in vivo. $\mathrm{CXCR} 4^{+} \mathrm{BMCs}$ freshly isolated from bone marrow rarely participated in myofiber formation and after transplantation in adult muscle are found between myofibers or differentiate into adipocytes. We showed here that CXCR4 ${ }^{+}$BMCs cocultured with myofibers in the presence of Sdf- 1 more efficiently participate in skeletal muscle regeneration then control cells, i.e., those that were freshly isolated from bone marrow. Previously, Sacchetti and coworkers documented that human CD146 ${ }^{+} \mathrm{BM}-\mathrm{MSCs}$ failed to contribute to myofiber formation in regenerating skeletal muscles [11]. However, it was also described by many authors that adherent BMCs isolated from the whole population of bone marrow cells improved muscle regeneration [15], participated in the formation of new myofibers, and were able to occupy the satellite cell niche $[16-23,59]$. However, it should be noted that the efficiency of BMC incorporation into new myofibers was very low. If BMCs were induced by NICD or Pax3 overexpression, the proportion of myofibers formed with their participation reached $11 \%$ or $16 \%$, respectively $[12,14,52]$.

\section{Conclusion}

We observed that CXCR4 ${ }^{+} \mathrm{BMCs}$ exposed to an environment specific for satellite cells (i.e., the satellite cell niche) were stimulated to adopt a myogenic fate (i.e., express MRFs and satellite cell-specific adhesion proteins). They were also able to fuse with myoblasts in vitro and more effectively participate in skeletal muscle regeneration, compared with control, freshly isolated from bone marrow, cells. Thus, we document that interaction with the specific niche could facilitate reprograming of multipotent stem cells. However, it should be noted that even after the myogenic commitment was induced in CXCR4 ${ }^{+}$BMCs by their contact with the satellite cell niche, their ability to form new myofibers in regenerating muscle was still low. Thus, the use of mesenchymal stem cells in therapy is still characterized by many limitations $[1,3,60,61]$.

\section{Abbreviations \\ $\beta$-gal: $\beta$-galactosidase; BMC: Bone marrow-derived cell; BM-MSC: Bone marrow-derived mesenchymal stem cell; Cdc42: Cell division control protein 42; ctx: Cardiotoxin; CXCR4: CXC chemokine receptor 4; ECM: Extracellular matrix; FAK: Focal adhesion kinase; G-CSF: Granulocyte colony-stimulating factor; HSC: Hematopoietic stem cell; MMP: Matrix metalloproteinase; MRF: Myogenic regulatory factor; NICD: Notch intracellular domain; Rac- 1: Ras-related C3 botulinum toxin substrate; Sdf-1: Stromal-derived factor-1}

\section{Acknowledgements}

The authors would like to thank Tomasz Skirecki for providing antibodies against NICD, as well as Katarzyna Jańczyk-Ilach and Władysława Stremińska for helping with the preparation of the experiments. Publication fee was covered by University of Warsaw founds.

\section{Funding}

The study was funded by the Ministry of Science and Higher Education through the Faculty of Biology, University of Warsaw intramural grant DSM \#14000/86-107423, 14000/86-110122, and 14000/86-112617. KK was supported by the START scholarship from the Foundation for Polish Science (FNP) (35.2017) 
and by an ETIUDA scholarship from the National Science Centre (2016/20/T/NZ3/ 00300). Experiments performed in PM's lab were financed by the Association Française contre les myopathies (AFM) by a fellowship to MDS, and by the Institut National de la Santé et de la Recherche Médicale (INSERM).

\section{Availability of data and materials}

Please contact the corresponding author for data requests.

\section{Authors' contributions}

KK designed the study, performed experiments and analysis, and prepared the figures. MDS and PM participated in the study design and performed experiments. MAC and EB participated in the study design and data analysis, and wrote the manuscript. All authors read and approved the final manuscript.

\section{Ethics approval}

Animal studies were approved by the Local Ethics Committee No. 1 in Warsaw, Poland (permit number 591/2014 and 046/2016) and Ethical Paris Descartes Cmmittee, France (CEEA34.PM.073.12) according to the European Union Directive on the approximation in laws, regulations and administrative provisions of the Member States regarding protection of animals used for experimental and scientific purpose $[42,43]$.

\section{Consent for publication}

Not applicable.

\section{Competing interests}

The authors declare that they have no competing interests.

\section{Publisher's Note}

Springer Nature remains neutral with regard to jurisdictional claims in published maps and institutional affiliations.

\section{Author details}

'Department of Cytology, Faculty of Biology, University of Warsaw, Miecznikowa 1 St, 02-096 Warsaw, Poland. 'Institut Cochin, Université Paris-Descartes, Centre National de la Recherche Scientifique (CNRS), UMR 8104, Paris, France. ${ }^{3}$ Institut National de la Santé et de la Recherche Médicale (INSERM) U1016, Paris, France.

Received: 29 June 2018 Revised: 22 August 2018

Accepted: 23 August 2018 Published online: 27 September 2018

\section{References}

1. Bianco P. "Mesenchymal" stem cells. Annu Rev Cell Dev Biol. 2014;30:677-704.

2. Bianco P. Stem cells and bone: a historical perspective. Bone. 2015;70:2-9.

3. Bianco P, Cao X, Frenette PS, Mao JJ, Robey PG, Simmons PJ, Wang CY. The meaning, the sense and the significance: translating the science of mesenchymal stem cells into medicine. Nat Med. 2013;19:35-42.

4. Friedenstein AJ, Chailakhyan RK, Gerasimov UV. Bone marrow osteogenic stem cells: in vitro cultivation and transplantation in diffusion chambers. Cell Tissue Kinet. 1987;20:263-72.

5. Tavassoli M, Crosby WH. Transplantation of marrow to extramedullary sites. Science. 1968;161:54-6.

6. Friedenstein AJ, Petrakova KV, Kurolesova Al, Frolova GP. Heterotopic of bone marrow. Analysis of precursor cells for osteogenic and hematopoietic tissues. Transplantation. 1968;6:230-47.

7. Friedenstein A, Kuralesova Al. Osteogenic precursor cells of bone marrow in radiation chimeras. Transplantation. 1971;12:99-108.

8. Owen M, Friedenstein AJ. Stromal stem cells: marrow-derived osteogenic precursors. CIBA Found Symp. 1988;136:42-60.

9. Friedenstein AJ. Stromal mechanisms of bone marrow: cloning in vitro and retransplantation in vivo. Haematol Blood Transfus. 1980;25:19-29.

10. Serafini M, Sacchetti B, Pievani A, Redaelli D, Remoli C, Biondi A, Riminucci $M$, Bianco P. Establishment of bone marrow and hematopoietic niches in vivo by reversion of chondrocyte differentiation of human bone marrow stromal cells. Stem Cell Res. 2014;12:659-72

11. Sacchetti B, Funari A, Remoli C, Giannicola G, Kogler G, Liedtke S, Cossu G, Serafini M, Sampaolesi M, Tagliafico E, et al. No identical "mesenchymal stem cells" at different times and sites: human committed progenitors of distinct origin and differentiation potential are incorporated as adventitial cells in microvessels. Stem Cell Rep. 2016;6:897-913.
12. Dezawa M, Ishikawa H, Itokazu Y, Yoshihara T, Hoshino M, Takeda S, Ide C, Nabeshima Y. Bone marrow stromal cells generate muscle cells and repair muscle degeneration. Science. 2005;309:314-7.

13. Shang Y, Zhang C, Wang S, Xiong F, Zhao C, Peng F, Feng S, Yu M, Li M, Zhang $Y$. Activated beta-catenin induces myogenesis and inhibits adipogenesis in BMderived mesenchymal stromal cells. Cytotherapy. 2007:9:667-81.

14. Gang EJ, Bosnakovski D, Simsek T, To K, Perlingeiro RC. Pax3 activation promotes the differentiation of mesenchymal stem cells toward the myogenic lineage. Exp Cell Res. 2008;314:1721-33.

15. Meyer S, Yarom R. Muscle regeneration and transplantation enhanced by bone marrow cells. Br J Exp Pathol. 1983;64:15-24.

16. Ferrari G, Cusella-De Angelis G, Coletta M, Paolucci E, Stornaiuolo A, Cossu $\mathrm{G}$, Mavilio F. Muscle regeneration by bone marrow-derived myogenic progenitors. Science. 1998;279:1528-30.

17. Gussoni E, Soneoka Y, Strickland CD, Buzney EA, Khan MK, Flint AF, Kunkel LM, Mulligan RC. Dystrophin expression in the $\mathrm{mdx}$ mouse restored by stem cell transplantation. Nature. 1999;401:390-4.

18. Fukada S, Miyagoe-Suzuki Y, Tsukihara H, Yuasa K, Higuchi S, Ono S, Tsujikawa K, Takeda S, Yamamoto $\mathrm{H}$. Muscle regeneration by reconstitution with bone marrow or fetal liver cells from green fluorescent protein-gene transgenic mice. J Cell Sci. 2002;115:1285-93.

19. LaBarge MA, Blau HM. Biological progression from adult bone marrow to mononucleate muscle stem cell to multinucleate muscle fiber in response to injury. Cell. 2002;111:589-601.

20. Palermo AT, Labarge MA, Doyonnas R, Pomerantz J, Blau HM. Bone marrow contribution to skeletal muscle: a physiological response to stress. Dev Biol. 2005;279:336-44.

21. Shi D, Reinecke $H$, Murry CE, Torok-Storb B. Myogenic fusion of human bone marrow stromal cells, but not hematopoietic cells. Blood. 2004;104:290-4.

22. Dreyfus PA, Chretien F, Chazaud B, Kirova Y, Caramelle P, Garcia L, ButlerBrowne G, Gherardi RK. Adult bone marrow-derived stem cells in muscle connective tissue and satellite cell niches. Am J Pathol. 2004;164:773-9.

23. Sherwood RI, Christensen JL, Weissman IL, Wagers AJ. Determinants of skeletal muscle contributions from circulating cells, bone marrow cells, and hematopoietic stem cells. Stem Cells. 2004;22:1292-304.

24. Chang NC, Rudnicki MA. Satellite cells: the architects of skeletal muscle. Curr Top Dev Biol. 2014;107:161-81.

25. Relaix F, Zammit PS. Satellite cells are essential for skeletal muscle regeneration: the cell on the edge returns centre stage. Development. 2012;139:2845-56.

26. Beauchamp JR, Heslop L, Yu DS, Tajbakhsh S, Kelly RG, Wernig A, Buckingham ME, Partridge TA, Zammit PS. Expression of CD34 and Myf5 defines the majority of quiescent adult skeletal muscle satellite cells. J Cell Biol. 2000;151:1221-34

27. Irintchev A, Zeschnigk M, Starzinski-Powitz A, Wernig A. Expression pattern of $\mathrm{M}$-cadherin in normal, denervated, and regenerating mouse muscles. Dev Dyn. 1994;199:326-37.

28. Wrobel E, Brzoska E, Moraczewski J. M-cadherin and beta-catenin participate in differentiation of rat satellite cells. Eur J Cell Biol. 2007;86:99-109.

29. Blanco-Bose WE, Yao CC, Kramer RH, Blau HM. Purification of mouse primary myoblasts based on alpha 7 integrin expression. Exp Cell Res. 2001;265:212-20.

30. Cohn RD, Henry MD, Michele DE, Barresi R, Saito F, Moore SA, Flanagan JD, Skwarchuk MW, Robbins ME, Mendell JR, et al. Disruption of DAG1 in differentiated skeletal muscle reveals a role for dystroglycan in muscle regeneration. Cell. 2002;110:639-48.

31. Cornelison DD, Filla MS, Stanley HM, Rapraeger AC, Olwin BB. Syndecan-3 and syndecan-4 specifically mark skeletal muscle satellite cells and are implicated in satellite cell maintenance and muscle regeneration. Dev Biol. 2001;239:79-94.

32. Bjornson CR, Cheung TH, Liu L, Tripathi PV, Steeper KM, Rando TA. Notch signaling is necessary to maintain quiescence in adult muscle stem cells. Stem Cells. 2012;30:232-42

33. Mourikis P, Sambasivan R, Castel D, Rocheteau P, Bizzarro V, Tajbakhsh S. A critical requirement for notch signaling in maintenance of the quiescent skeletal muscle stem cell state. Stem Cells. 2012;30:243-52.

34. Ciemerych MA, Archacka K, Grabowska I, Przewozniak M. Cell cycle regulation during proliferation and differentiation of mammalian muscle precursor cells. In: Kubiak JZ, editor. Cell cycle in development, results and problems in cell differentiation. Volume 53. Berlin Heidelberg: SpringerVerlag; 2011. p. 498-507.

35. Mourikis $P$, Tajbakhsh S. Distinct contextual roles for notch signalling in skeletal muscle stem cells. BMC Dev Biol. 2014;14:2. 
36. Bentzinger CF, Wang YX, Dumont NA, Rudnicki MA. Cellular dynamics in the muscle satellite cell niche. EMBO Rep. 2013;14:1062-72.

37. Yin $\mathrm{H}$, Price $F$, Rudnicki MA. Satellite cells and the muscle stem cell niche. Physiol Rev. 2013;93:23-67.

38. Dinulovic I, Furrer R, Handschin C. Plasticity of the muscle stem cell microenvironment. Adv Exp Med Biol. 2017:1041:141-69.

39. Birbrair A. Stem cell microenvironments and beyond. Adv Exp Med Biol. 2017;1041:1-3

40. Brzoska E, Kowalski K, Markowska-Zagrajek A, Kowalewska M, Archacki R, Plaskota I, Streminska W, Janczyk-llach K, Ciemerych MA. Sdf-1 (CXCL12) induces CD9 expression in stem cells engaged in muscle regeneration. Stem Cell Res Ther. 2015;6:46.

41. Kucia M, Jankowski K, Reca R, Wysoczynski M, Bandura L, Allendorf DJ, Zhang J, Ratajczak J, Ratajczak MZ. CXCR4-SDF-1 signalling, locomotion, chemotaxis and adhesion. J Mol Histol. 2004;35:233-45.

42. Close B, Banister K, Baumans V, Bernoth EM, Bromage N, Bunyan J, Erhardt W, Flecknell P, Gregory N, Hackbarth $\mathrm{H}$, et al. Recommendations for euthanasia of experimental animals: part 1. DGXI of the European Commission. Lab Anim. 1996;30:293-316.

43. Close B, Banister K, Baumans V, Bernoth EM, Bromage N, Bunyan J, Erhardt W, Flecknell P, Gregory N, Hackbarth H, et al. Recommendations for euthanasia of experimental animals: part 2. DGXT of the European Commission. Lab Anim. 1997:31:1-32.

44. Rosenblatt JD, Lunt Al, Parry DJ, Partridge TA. Culturing satellite cells from living single muscle fiber explants. In Vitro Cell Dev Biol Anim. 1995;31:773-9.

45. Archacka K, Pozzobon M, Repele A, Rossi CA, Campanella M, De Coppi P. Culturing muscle fibres in hanging drop: a novel approach to solve an old problem. Biol Cell. 2014;106:72-82.

46. Seluanov A, Vaidya A, Gorbunova V. Establishing primary adult fibroblast cultures from rodents. J Vis Exp. 2010;(44). https://doi.org/10.3791/2033

47. Mendez-Ferrer S, Michurina TV, Ferraro F, Mazloom AR, Macarthur BD, Lira SA, Scadden DT, Ma'ayan A, Enikolopov GN, Frenette PS. Mesenchymal and haematopoietic stem cells form a unique bone marrow niche. Nature. 2010; 466:829-34.

48. Kowalski K, Kolodziejczyk A, Sikorska MH, Placzkiewicz J, Cichosz P, Kowalewska M, Streminska W, Janczyk-llach K, Koblowska M, Fogtman A, et al. Stem cells migration during skeletal muscle regeneration-the role of Sdf-1/Cxcr4 and Sdf-1/Cxcr7 axis. Cell Adh Migr. 2017:11(4):384-98.

49. Brzoska E, Kowalewska M, Markowska-Zagrajek A, Kowalski K, Archacka K, Zimowska M, Grabowska I, Czerwinska AM, Czarnecka-Gora M, Streminska W, et al. Sdf-1 (CXCL12) improves skeletal muscle regeneration via the mobilisation of Cxcr4 and CD34 expressing cells. Biol Cell. 2012;104:722-37.

50. Kowalski K, Archacki R, Archacka K, Stremińska W, Paciorek A, Gołąbek M, Ciemerych MA, Brzoska E. Stromal derived factor-1 and granulocyte-colony stimulating factor treatment improves regeneration of Pax7-/- mice skeletal muscles. J Cachexia Sarcopenia Muscle. 2016;7(4):483-96. https://doi. org/10.1002/jcsm. 12092

51. Wakitani S, Saito T, Caplan Al. Myogenic cells derived from rat bone marrow mesenchymal stem cells exposed to 5-azacytidine. Muscle Nerve. 1995;18: $1417-26$.

52. Gang EJ, Darabi R, Bosnakovski D, Xu Z, Kamm KE, Kyba M, Perlingeiro RC Engraftment of mesenchymal stem cells into dystrophin-deficient mice is not accompanied by functional recovery. Exp Cell Res. 2009:315:2624-36.

53. Sakai H, Fukuda S, Nakamura M, Uezumi A, Noguchi YT, Sato T, Morita M, Yamada H, Tsuchida K, Tajbakhsh S, Fukada SI. Notch ligands regulate the muscle stem-like state ex vivo but are not sufficient for retaining regenerative capacity. PLoS One. 2017;12:e0177516.

54. Quattrocelli M, Costamagna D, Giacomazzi G, Camps J, Sampaolesi M. Notch signaling regulates myogenic regenerative capacity of murine and human mesoangioblasts. Cell Death Dis. 2014;5:e1448.

55. Kondoh K, Sunadome K, Nishida E. Notch signaling suppresses p38 MAPK activity via induction of MKP-1 in myogenesis. J Biol Chem. 2007;282:3058-65.

56. Mourikis P, Gopalakrishnan S, Sambasivan R, Tajbakhsh S. Cell-autonomous notch activity maintains the temporal specification potential of skeletal muscle stem cells. Development. 2012;139:4536-48.

57. Wen Y, Bi P, Liu W, Asakura A, Keller C, Kuang S. Constitutive notch activation upregulates Pax7 and promotes the self-renewal of skeletal muscle satellite cells. Mol Cell Biol. 2012;32:2300-11.

58. Bi P, Yue F, Sato Y, Wirbisky S, Liu W, Shan T, Wen Y, Zhou D, Freeman J, Kuang S. Stage-specific effects of notch activation during skeletal myogenesis. eLife. 2016;5. https://doi.org/10.7554/eLife.17355.
59. Brazelton TR, Nystrom M, Blau HM. Significant differences among skeletal muscles in the incorporation of bone marrow-derived cells. Dev Biol. 2003; 262:64-74.

60. Cantaluppi V, Biancone L, Quercia A, Deregibus MC, Segoloni G, Camussi G. Rationale of mesenchymal stem cell therapy in kidney injury. Am J Kidney Dis. 2013;61:300-9.

61. Papaccio F, Paino F, Regad T, Papaccio G, Desiderio V, Tirino V. Concise review: cancer cells, cancer stem cells, and mesenchymal stem cells: influence in cancer development. Stem Cells Transl Med. 2017;6:2115-25.

\section{Ready to submit your research? Choose BMC and benefit from:}

- fast, convenient online submission

- thorough peer review by experienced researchers in your field

- rapid publication on acceptance

- support for research data, including large and complex data types

- gold Open Access which fosters wider collaboration and increased citations

- maximum visibility for your research: over $100 \mathrm{M}$ website views per year

At BMC, research is always in progress.

Learn more biomedcentral.com/submissions 